\title{
FINANCIAL INCLUSION MODEL ON THE DEVELOPMENT OF BATIK SMES IN CIREBON REGENCY
}

\author{
Amir Hamzah*, Dadang Suhendar \\ Universitas Kuningan, Indonesia
}

\begin{abstract}
ABSTRACT: This study analyzes the financial inclusion model on Batik SMEs' development in Cirebon Regency. Six constructs emerge as the objects of interest are financial literacy, financial technology, social capital, capital structure decisions, financial inclusion, and business development. 176 Batik-Cirebon artisans fill the questionnaires under the non-probability sampling technique and are analyzed using CB-SEM. The results prove that financial literacy, financial technology, social capital, capital structures positively affect financial inclusion, and financial inclusion positively increases the SMEs' business development in Cirebon Regency.
\end{abstract}

Keywords: Capital Structure Decisions, Financial Inclusion, Financial Literacy, Financial Technology, Social Capital.

*Corresponding author : amir.hamzah@uniku.ac.id

DOI: $10.24252 /$ minds.v7i2.16512

ISSN-E: 2597-6990

ISSN-P: 2442-4951

http://journal.uin-alauddin.ac.id/index.php/minds 


\section{INTRODUCTION}

The Covid-19 pandemic has had a significant impact on the economic order in Indonesia and the world. The impact that is felt is the uncertainness that never stops and continuously so that the economic order experiences uncertainty in which the business or business between developing or going bankrupt. One of the affected is Small and Medium Enterprises (SMEs), SMEs in Indonesia have a crucial role in boosting economic growth. The Ministry of Trade reveals that as of 2019 , they share $60.34 \%$ of GDP in Indonesia and $96.99 \%$ to $97.22 \%$ employment rate.

Amid the Covid-19 pandemic, the SMEs are under severe threats, with millions of them closed their businesses. Under these conditions, SMEs do not even contribute to maintaining the national or regional economy, and the growth is difficult to predict. Indonesian SMEs are scattered throughout the region, with specific interest to Cirebon's batik. It functions as the hallmark of Indonesia globally with special recognition of UNESCO as a world heritage. The unique fabrics with various patterns and motifs contain deep philosophical meanings. The Covid-19 decreases batik sales by almost $90 \%$. Furthermore, it is derailed by several internal factors (capital, production, marketing, and human resources) and external factors (Developers and SMEs coaching). Under the Otoritas Jasa Keuangan (Financial Service Authority), the Indonesian government provides SMEs with a solution under the financial inclusion effort.

Financial inclusion is an effort to encourage the financial system in all aspects of life, thereby encouraging quality economic growth while reducing poverty. However, this work is still imperfect with a $49 \%$ rate. According to the World Bank (2016), the condition occurs because the community is still very minimal in utilizing financial institutions, especially SMEs, to grow their business. Several factors influence financial inclusion, namely, financial literacy, social capital, financial technology, and capital structure decisions. Several studies reveal that it takes sufficient knowledge to access financial services (Bongomin et al., 2017) because business owners will first analyze the advantages and disadvantages before deciding to take financing (Bartlet et al., 2020). However, if there is no access to financial services, then it will be a waste. In general, this is due to low levels of financial literacy and a lack of trust in financial institutions (Hamzah \& Suhardi, 2019). This figure indicates the critical role of financial literacy and financial inclusion s to expand cooperation and work with many parties to improve public financial literacy, one of which is social capital.

Social capital is about solidarity, confidence, facilitating running a business, and social relationships involving family, friends, coworkers, community, or group (Felicio et,al:2014). Social capital is expected to be one of the alternatives in improving financial inclusion. On the other hand, capital structure decisions for SME actors are essential in financing debt and capital themselves. This budgeting structure will impact financial inclusion because fintech facilitates all SME activities, encourages innovation, and easier access in fulfilling financing needs. When financial inclusion increases, the development of SMEs may follow. They will be more advanced if they realize how important 
financial management is in financing their business. This study contributes to the minor discussion of social capital and financial inclusion as well as capital structure of the local SMEs. This study highlights the approach to develop local culture business of Cirebon, Indonesia. Based on the above description, researchers are interested in researching and referring to previous empirical studies' results by considering that there are still problems with the ability and knowledge of businesses in conducting financial management or financial literacy, social capital, and financial technology SMEs Batik Cirebon Regency.

\section{THEORETICAL REVIEW}

\section{Financial Literacy}

Financial literacy is an integral dimension of a person who has the ability and confidence to use the knowledge and make finance decisions (Huston, 2010). It is knowledge, skills, and confidence that affects attitudes and behaviors to improve decision-making and financial management to achieve well-being (Hanson \& Olson, 2018; Said et al., 2019). Organization for Economic Cooperation and Development (OECD) defines financial literacy as a combination of awareness, knowledge, skills, attitudes, and behaviors needed to make sound financial decisions to achieve financial individual well-being.

\section{Social Capital}

Haridison (2013) in (Fathy, 2019) social capital is: (1) a set of actual and potential resources; (2) the entity consists of several aspects of the social structure, and it facilitates the actions of the individuals present in the structure; (3) horizontal associations; (3) the actor's ability to guarantee benefits; (4) information; (5) norms; (6) values; (7) reciprocity; (8) cooperation; (9) network. Social capital may refer to norms or networks that allow taking collective action. Social capital is the aggregate actual or potential resources tied to realize a network to institutionalize mutually beneficial friendships. Social networks are constructed through investment strategies oriented towards the institutionalization of group relations that can be used as a reliable source for profit. Social capital captures social organizations, social networks, mutual norms that facilitate coordination and cooperation, and mutual benefit. The importance of cooperation in group activities is strengthened by mutual trust and norms. Mutual trust can be explained from interactions based on confidence that others will respond as expected and mutual support.

\section{Financial Technology}

Financial Technology (FinTech) is a combination of technology and financial features or can also be interpreted as innovation in the financial sector with a touch of modern technology (Moenjak et al., 2020). Moreover, financial technology is (1) Third-party payment systems. Examples are EC cross-borders, online-to-offline $(\mathrm{O} 2 \mathrm{O})$, mobile payment systems, and payment platforms that provide services such as bank payments and transfers. (2) Peer-to-Peer (P2P) 
Lending is a platform that brings together lenders and borrowers over the internet. Peer-to-Peer Lending provides credit mechanisms and risk management. This platform helps lenders and borrowers meet the needs of and make efficient use of money. (3) Crowdfunding is a type of FinTech in which a concept or product such as design, programs, content, and creative works are published in general, and people who are interested and want to support the concept or product may provide financial support. Crowdfunding can be used to reduce financial needs entrepreneurship and predict market demand (Fisher et al., 2017).

\section{Capital Structure Decisions}

In running its business, most SMEs prefer to use their funds rather than borrow from others (Hirdinis, 2019; Hovakimian et al., 2001). The reason is simple: if using the funds themselves will be easier to control, and there is no obligation to pay installments, and based on the premise that internal management is better at knowing its real value than outside investors. Pecking order theory is more relevant to the SME sector due to the relatively more significant asymmetry of information and higher external equity costs (Sohilauw, 2018).

\section{Financial Inclusion}

Finance Inclusion is the provision of access for marginalized people (more to the poor) to own and use financial system services (Pulungan, 2019) and According to the Department of Financial Access Development and SMEs Bank Indonesia (2014) states that financials are inclusively defined as a national strategy aimed at economic growth through income equality, poverty alleviation, and financial system stability. An inclusive financial vision is to realize the financial system accessible to all walks of life to encourage economic growth, poverty reduction, equalization of income, and the creation of financial system stability in Indonesia. (DPAU BI, 2014).

\section{METHODOLOGY}

The population of this research is SMEs Batik In Cirebon Regency. This research sample is batik entrepreneurs or SMEs in Cirebon regency with as many as 176 owners. This type of research is descriptive and verification research, and the methods used, are descriptive survey methods and explanatory survey methods to explain the relationship between variables through hypothesis testing in the field. The data in this study is primary data. Primary data is obtained from the first source, either individual or individual, such as from interviews or questionnaires that researchers commonly do.

Data Analysis Tool (1) Descriptive Statistics = provides a complete empirical picture of the study's data. (2) Verificative statistics = tiered analysis is described in the diagram's path to analyze the logic of interconnectedness and the sequence of events between research variables. To test models and hypotheses used structural equation model analysis (SEM) as well as the 
following stages: (a) Testing Measuring Instruments (Validity Test \& Reliability Test) (b) Classic Assumption Test (Outlier Detection, Normality Assumption) (c) Hypothesis Test using SEM: (1) SEM assumption, (2) SEM procedure approach, (3) SEM modeling procedure stages (model specifications, model identification, estimation, match test, respecification), (4) SEM analysis tools using AMOS Software.

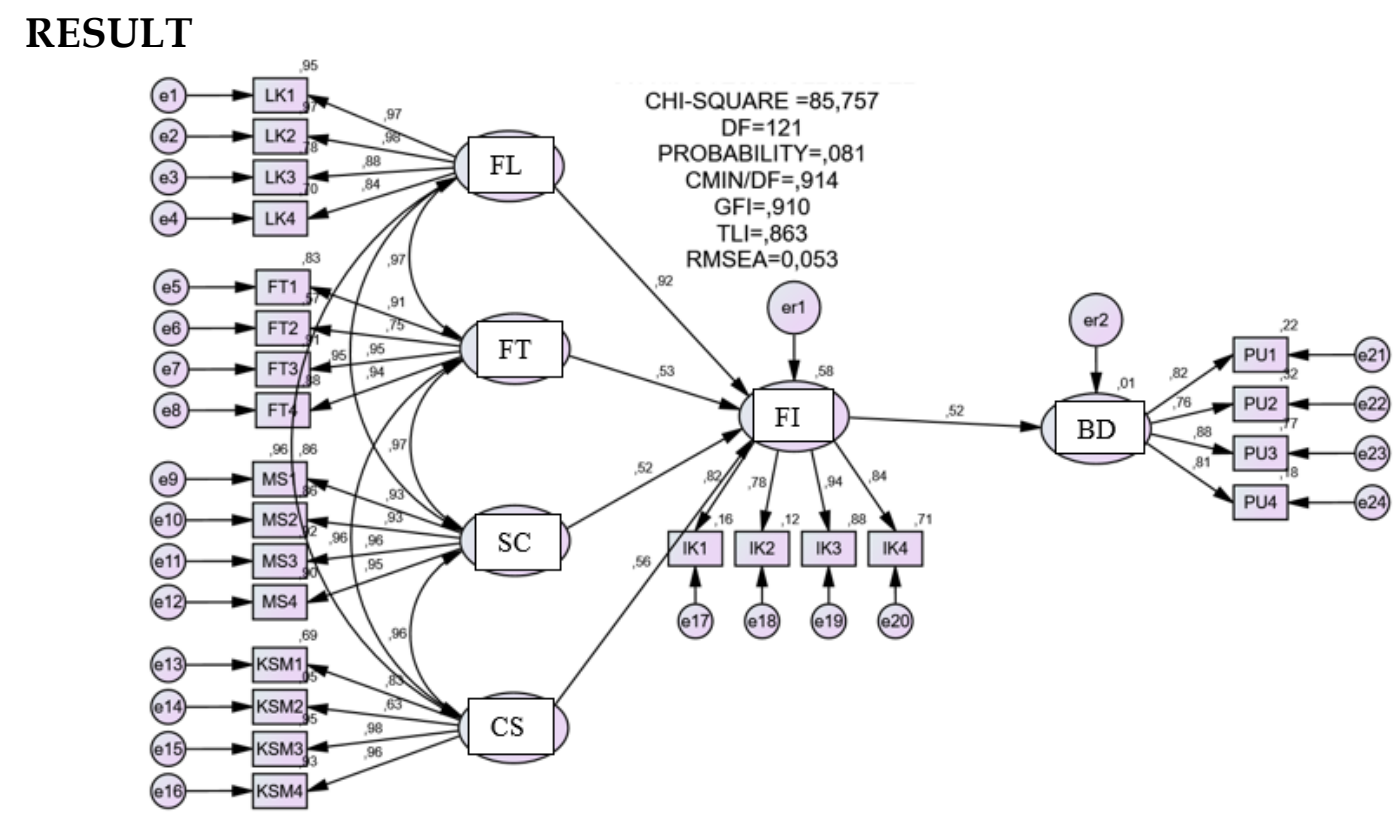

Figure 1. Structural Equation Model (SEM)

Figure 1 comprises all investigated correlations among variables, namely financial literacy, financial technology, social capital, decisions on the structure of the investment capital against financial inclusion, and financial inclusion affect the development of BATIK SMEs in Cirebon Regency.

Table 1. Summary of Goodness of Fit Index

\begin{tabular}{cccc}
\hline Criterion & Cut-of-Value & $\begin{array}{c}\text { Analysis } \\
\text { Results }\end{array}$ & $\begin{array}{c}\text { Model } \\
\text { Evaluation }\end{array}$ \\
\hline Chi-Square & $\begin{array}{c}\text { Small Is } \\
\text { Expected }\end{array}$ & 85,757 & Good Fit \\
Significance & $\geq 0,005$ & 0,004 & Good Fit \\
Probability & $\leq 2,00$ atau 3,00 & 0,914 & Good Fit \\
CMIN/DF & $\geq 0,90$ & 0,910 & Good Fit \\
GFI & $\geq 0,90$ & 0,939 & Good Fit \\
AGFI & $\geq 0,90$ & 0,863 & Marginal Fit \\
TLI & $\geq 0,90$ & 0,980 & Good Fit \\
CFI & $\geq 0,90$ & 0,911 & Good Fit \\
NFI & $\leq 0,08$ & 0,053 & Good Fit \\
RMSEA &
\end{tabular}

Source: AMOS Output 
The test results in table 1 highlight essential goodness of fit index, namely Chi-Square, Significance Probability, CMIN/DF, GFI, AGFI, TLI, CFI, NFI, and RMSEA have a decent value that is the value hinted at in calculating the goodness of fit. All goodness of fit criteria is eligible for constructing a path analysis as the values are within the expected range and ready for hypothesis testing. Table 2 compiles the investigated relationship as follows.

Table 2. Hypothesis Testing

\begin{tabular}{ccccc}
\hline Hypothesis & Path & t-value & $\boldsymbol{P}$ & Results \\
\hline H1 & FL $\rightarrow$ FI & 2,134 & 0,033 & Accepted \\
H2 & FT $\rightarrow$ IK & 4,639 & 0,023 & Accepted \\
H3 & SC $\rightarrow$ IK & 5,901 & 0,018 & Accepted \\
H4 & CS $\rightarrow$ IK & 3,494 & 0,021 & Accepted \\
H5 & FI $\rightarrow$ Bus. Dev. & 7,673 & 0,008 & Accepted \\
\hline
\end{tabular}

Source: Processed Data, 2020

\section{DISCUSSION}

Based on the analysis test results in hypothesis 1, financial literacy positively influences financial inclusion. The results show the CR and $P$ values in hypothesis 1 qualify so that hypothesis $\mathbf{1}$ is accepted. Financial literacy has a positive effect on financial inclusion, indicating that batik SMEs have good financial literacy, such as managing business finance regularly, distinguishing which finances for business and personal purposes, pay attention to the importance of financial reporting based on the prevailing accounting standards and rules. The SMEs business will not have difficulty in financial management, when batik SMEs actors apply basic knowledge of financial management, credit management, savings and investment management, and financial risk management in their business. SMEs are not only good at financial management, but batik business will develop well. On the other hand, as the business grows, this high level of financial literacy will impact financial inclusion in Indonesia, especially as Batik SMEs are aware of the importance of financial management and financial reporting based on existing accounting rules. This finding is in line with Hamzah \& Suhardi (2019), which stated that financial literacy could increase financial inclusion, supported by Yanti's (2019) work who found a positive effect on financial inclusion.

Based on the analysis test results in hypothesis 2, financial technology positively influences financial inclusion. The results show the $C R$ and $P$ values in hypothesis 2 qualify so that hypothesis $\mathbf{2}$ is accepted. Batik artisans may benefit from technological advancement, especially technology-based financial management systems. Many financing offers from technology-based financial institutions make it easier for Batik SMEs to get funds. Transactions are faster tailored to their business needs. At this time, batik SMEs are required to be literate towards technology, so they inevitably want all online-based activities, especially if there is a funding offer, fast transactions they have to understand 
about financial technology. Suppose SMEs understand that financial technology will have an impact on financial inclusion. In that case, SMEs are more capable of accessing existing products and financial services based online, so that the more understanding SMEs have about online-based financial institutions, the financial inclusion will increase. This result is in line with research conducted by (Hamzah \& Suhardi, 2019), which stated financial technology has a significant effect on financial inclusion, along with other studies (Aliyah, 2019; Pambudianti et al., 2020; Sugiarti et al., 2019; Winarto, 2020; Xue et al., 2016).

Based on the analysis test results in hypothesis 3 , social capital positively influences financial inclusion. The results showed $\mathrm{CR}$ and $\mathrm{P}$ values in hypothesis 3 within the accepting range so that hypothesis 3 was accepted. Suppose the batik SME actors understand that social capital is a dimension built on values, perceptions, institutions, and mechanisms in positive activities to empower the community. Entrepreneurship has a significant role in managing businesses to develop by openness to financial inclusion. Some studies support the findings' notion (Azhari et al., 2018; Delyana Rahmawany Pulungan, 2019; Saputra \& Dewi, 2017).

Based on the analysis test results on hypothesis 4, there is a positive influence on capital structure decisions on financial inclusion. The results showed $C R$ and $P$ values in hypothesis 4 qualified so that hypothesis 4 was accepted. Capital structure decisions positively affect financial inclusion, meaning that the increasing decision of the capital structure will increase financial inclusion, where most SMEs prefer to use their own funds rather than borrow from others. The reason is simple if using the funds themselves will be easier to control, and there is no obligation to pay installments, and based on the premise that internal management is better because it knows the actual value of the company than outside investors so that SMEs understand the decision of the capital structure and the end of the financial inclusion will increase (Sohilauw, 2018).

Based on the analysis test results on hypothesis 5, there is a positive influence of financial inclusion on business development. The results show the $\mathrm{CR}$ and $\mathrm{P}$ values in hypothesis 5 qualify so that hypothesis 5 is accepted. Financial inclusion has a positive effect on business development, meaning that with the increasing financial inclusion of SMEs batik, the business development of SMEs batik will increase, where the SMEs batik players understand the concept of SMEs' financial education and property rights, Financial Services, Consumer protection. This finding is in line with Yanti (2019), supporting financial education's impact on business development.

The community's property rights affect the development of the business means that the assistance of the addition of collateral for the application of financing for the expansion of capital can help the development of SMEs businesses better. The government plays a critical role in supporting local SMEs because the non-cash subsidies may ease their burden, and indirectly, the materials they buy become cheaper and become more profitable. The Kredit Usaha Rakyat (governmental small business loans) is also straightforward in 
borrowing capital for the business to grow more. Consumer protection affects business development. Batik SMEs' development in Cirebon will increase if consumer protection goes well because, with consumer protection, Batik businesses become safe and unstoppable if they want to save their money in financial institutions. This finding is in line with Steelyana (2013), which states that financial inclusion can be carried out thoroughly in Indonesia and significantly impact SMEs entrepreneurs, especially for entrepreneurs.

\section{Conclusion}

Based on the results of research and discussion, the conclusions are: (1) Financial literacy has a positive effect on financial inclusion, meaning that the increase in financial literacy will also increase. (2) Financial technology has a positive effect on financial inclusion, meaning that the increase in Financial Technology will increase. (3) Social capital has a positive effect on financial inclusion, meaning that social capital increase will increase financial inclusion. (4) Capital structure decisions have a positive effect on financial inclusion, meaning that the increasing decision of the capital structure will increase financial inclusion. (5) Financial inclusion has a positive effect on business development means that the increase in financial inclusion will increase the business of MSMEs batik will increase as well.

\section{Further Study}

This research aims to provide information on the Financial Inclusion model to Batik SMEs business in Cirebon Regency. The results of this research can make information for Batik SMEs, Government, and Academics. This study is limited as the investigated topic only cover the specific business of Batik SMEs. While other entrepreneurship efforst are potentially serve other topic enquiries, future studies may combine a national-based data and the specific investigation in the SMEs's sectors.

\section{REFERENCES}

Azhari, F., Mawardi, M. K., Administrasi, F. I., \& Brawijaya, U. (2018). Peran Modal Sosial Dalam Pengembangan Jaringan Usaha Kecil Menengah ( Studi Kasus pada Rumah Makan Padang ). 59(1), 153-162.

Bartlet, W., Đulić, K., \& Kmezić, S. (2020). The impact of fiscal decentralisation on local economic development in Serbia. Lex Localis. https://doi.org/10.4335/18.1.143-163(2020)

Bongomin, G. O. C., Mpeera Ntayi, J., \& C. Munene, J. (2017). Institutional framing and financial inclusion. International Journal of Social Economics. https://doi.org/10.1108/ijse-02-2015-0032

Delyana Rahmawany Pulungan, A. N. (2019). "Pengaruh Literasi Keuangan dan Modal Sosial Terhadap Inklusi Keuangan Mahasiswa." SAMBIS, 132-142.

Fathy, R. (2019). Modal Sosial: KOnsep, Inklusivitas dan Pemberdayaan 
Masyarakat. Pemikiran, Jurnal Volume, Sosiologi, 6(1), 1-17.

Fisher, G., Kuratko, D. F., Bloodgood, J. M., \& Hornsby, J. S. (2017). Erratum:

"Legitimate to whom? The challenge of audience diversity and new venture legitimacy" (Journal of Business Venturing (2017) 32 (5271)(S0883902616302087)(10.1016/j.jbusvent.2016.10.005)). In Journal of Business Venturing (Vol. 32, Issue 1, pp. 128-129). https://doi.org/10.1016/j.jbusvent.2016.11.003

Hamzah, A., \& Suhardi, D. D. (2019). Tingkat Literasi Keuangan Dan Financial Technology Pada Pelaku Usaha Mikro, Kecil, Dan Menengah (UMKM) Kabupaten Kuningan. Jurnal Ilmiah Manajemen Fakultas Ekonomi), 5(2), 97108.

Hanson, T. A., \& Olson, P. M. (2018). Financial literacy and family communication patterns. Journal of Behavioral and Experimental Finance. https://doi.org/10.1016/j.jbef.2018.05.001

Hirdinis, M. (2019). Capital structure and firm size on firm value moderated by profitability. International Journal of Economics and Business Administration. https://doi.org/10.35808/ijeba/204

Hovakimian, A., Opler, T., \& Titman, S. (2001). The Debt-Equity Choice. The Journal of Financial and Quantitative Analysis, 36(1), 1. https:/ / doi.org/10.2307/2676195

Huston, S. J. (2010). Measuring Financial Literacy.

Iko Putri Yanti, W. (2019). Pengaruh Inklusi Keuangan Dan Literasi Keuangan Terhadap Kinerja Umkm Di Kecamatan Moyo Utara. Jurnal Manajemen Dan Bisnis, 2(1). https://doi.org/10.37673/jmb.v2i1.305

Lia Muhibatul Aliyah, N. (2019). Pengaruh Layanan Keuangan Berbasis Teknologi ( Fintech ) terhadap Literasi Keuangan Masyarakat Dago Atas , Bandung. Prosiding Manajemen, 5(1), 649-656.

Moenjak, T., Kongprajya, A., \& Monchaitrakul, C. (2020). AND BORROWING: THE CASE Asian Development Bank Institute (Issue 1100).

Pambudianti, F. F. R., Purwanto, B., \& Maulana, T. N. A. (2020). The implementation of fintech: Efficiency of MSMEs loans distribution and users' financial inclusion index. Jurnal Keuangan Dan Perbankan, 24(1), 68-82. https://doi.org/10.26905/jkdp.v24i1.3218

Said, S., Amiruddin, A. M. A., Asad, A., Rustan, C., \& Sofyan, A. S. (2019). Managing with Sharia: Strengthening Sharia Banking Spiritual Literation. Jurnal Minds: Manajemen Ide Dan Inspirasi, 6(2), 161. https:// doi.org/10.24252/minds.v6i2.10297

Saputra, R. S., \& Dewi, A. S. (2017). Peran Modal Sosial Sebagai Mediator Literasi Keuangan Dan Inklusi Keuangan Pada Kaum Muda Di Indonesia ( Studi Kasus Pada Komunitas Investor Saham Pemula ). 3, 243-257.

Sohilauw, M. I. (2018). Moderasi Inklusi Keuangan Terhadap Hubungan Literasi Keuangan dan Keputusan Struktur Modal UKM. Jurnal, Jbima Dan, Bisnis, 6(2), 92-114.

Steelyana, E. (2013). Perempuan dan Perbankan: Sebuah Tinjauan Tentang Peran Inklusi Keuangan terhadap Pengusaha UMKM Perempuan di Indonesia. 
The Winners, 14(2), 95. https://doi.org/10.21512/tw.v14i2.649

Sugiarti, E. N., Diana, N., \& Mawardi, M. C. (2019). Peran Fintech Dalam Meningkatkan Literasi Keuangan Pada Usaha Mikro Kecil Menengah Di Malang. E-Jra, 8(4), 90-104.

Winarto, W. W. A. (2020). Peran Fintech dalam Usaha Mikro Kecil dan Menengah (UMKM). Jesya (Jurnal Ekonomi \& Ekonomi Syariah), 3(1), 61-73. https://doi.org/10.36778/jesya.v3i1.132

Xue, P., Wang, Z., Zhang, R., Wang, Y., \& Liu, S. (2016). Highly efficient measurement technology based on hyper-spectropolarimetric imaging. Zhongguo Jiguang/Chinese Journal of Lasers, 43(8), 107-128. https://doi.org/10.3788/CJL201643.0811001 